\title{
Communication frictions in banking organizations: Evidence from credit score lending
}

\author{
Stefano Filomeni, Gregory F. Udell, and Alberto Zazzaro*
}

\begin{abstract}
By using mid-corporate loan-level data on loan approval decisions collected from a large European bank, we investigate whether spatially-based bank organizational frictions affect borrowers' credit availability.
\end{abstract}

Keywords: Communication frictions, bank organization, soft information, credit score lending

JEL codes: G21, L14, D82

\footnotetext{
* Stefano Filomeni (corresponding author), stefano.filomeni@essex.ac.uk, University of Essex, Essex Business School, Finance Group (Colchester, UK); Gregory F. Udell, gudell@indiana.edu, Kelley School of Business, Indiana University, and MoFiR; and Alberto Zazzaro, alberto.zazzaro@unina.it, University of Naples Federico II, Polytechnic University of Marche, MoFiR, and CSEF. We thank an anonymous referee for helpful comments.
} 


\section{Introduction}

Credit scoring technologies (CSTs) can be thought of as both an information technology, which allows a bank to share and disseminate relevant information on the riskiness of loan applicants across the organization, and a communication technology, which allows a bank to standardize and improve communication between loan managers at different bank hierarchical levels (Bloom et al., 2014). Whatever the possible effects on optimal delegation of loan-approval authority within the bank organization (Mocetti et al., 2017), CSTs may mitigate organizational frictions which prevent the effective transmission of information at distance within the bank's hierarchy (Stein, 2002). More precisely, the adoption of CSTs potentially allows the extrusion of hard and "hardenable" soft information available to loan officers locally into numerical scores which are easily and unambiguously transmissible along the bank's hierarchy. To the extent that CSTs deliver on this objective, conditional on the credit score and other relevant characteristics of the applicant, the likelihood of loan approval and the amount of granted loans should be unaffected by the geographical distance between the loan officer originating the credit score and the senior manager with the ultimate loan approval authority. However, depending on the extent that CSMs incorporate soft information "hardened" into a numerical scale by the loan officer responsible for the credit scoring, the subjectivity and the different environments of who collects and who interprets information may still matter (Liberti and Petersen, 2017). Thus, the use of CSTs may not eliminate communication frictions in the bank hierarchy. Applicants receiving the same credit score can have a different access to credit according to the distance covered by the loan application within the organization from the branch where loan officer who originates the credit score resides and the branch where the senior officer makes the loan approval decision.

In fact, recent studies indicate that the "hardening" of soft information in credit scoring encounters significant limits reflecting communication frictions within the bank's organizational hierarchy (Brown et al., 2015; Gropp and Guettler, 2018). In particular, in a companion paper we show that spatially-based organizational frictions (proxied by the functional distance between the loan officer 
compiling the credit score and the bank's headquarters) affects the propensity of loan officers to "harden" soft information in credit scoring and the approval time for applicants (Filomeni et al., 2020).

In this paper, we look at the bank's lending decision. Our dependent variables are the approval itself and loan amount. Specifically, in this paper we analyze whether access to credit of equally-rated applicants varies with the Hierarchical distance between the bank's branch responsible for the credit scoring and the bank's branch responsible for the loan approval. We find evidence of the persistence of spatially-based organizational frictions in credit score lending. Specifically, our results indicate that, conditional on the borrower's final rating, the likelihood of loan approval is unaffected by the hierarchical distance. The amount of credit made available to applicants, however, significantly decreases with the hierarchical distance from the branch of the loan officer originating the credit score. Moreover, the adverse effect of hierarchical distance on credit amount is especially strong when the final rating incorporates uncodifiable soft information injected by the loan officer by overriding the automated financial score.

Our results are closely related and consistent with those documented by Liberti and Mian (2009) and Liberti (2018) for the case of an Argentinian bank, in which the reliance of lending decisions on soft information "hardened" in credit scoring gets diluted the higher is the loan approver in the bank's hierarchy.

The rest of the paper is organized as follows. In Section 2, we describe the data and the estimated model. In Section 3, we present our main findings. In Section 4, we conclude.

\section{Data and estimated models}

The laboratory for our exploration is the corporate loan underwriting activity of a large European multinational bank. The data used in this study have been manually collected from the credit folders of all (550) mid-corporate loan applications managed (either eventually approved or denied) by the Corporate and Investment Banking Division of a major European bank from September 2011 to 
September 2012. ${ }^{1}$ The mid-corporate segment comprises firms having annual turnover between 150 million and 1 billion euros. This segment of the loan market is typically less plagued by problems of information opaqueness than SMEs. For this reason, credit score lending to the mid-corporate segment should be less vulnerable to problems of information transmission across the bank's organizational structure and, if something, should bias us against finding an impact of hierarchical distance on lending decisions.

Each credit folder contains very granular information on applicant and loan characteristics, the identity and location of the loan officer in charge of the credit application and the hierarchical level at which the loan is ultimately approved or denied. In particular, we have detailed information on the whole rating process, knowing the final rating received by the loan application, and the two intermediate statistical and integrated ratings. The former reflects the probability of default based on hard information available to the loan officer extracted from firm's financial statements and repayment history. The integrated rating incorporates soft information about several business and market characteristics (e.g. the positioning strategy of the company in the market, the future investment projects, the management quality) "hardened" into the score by the loan officer who completes a predefined qualitative questionnaire specifically required by the bank.

Firstly, we explore whether, conditional on the applicant's final rating, the likelihood of having approved the loan application and the amount of credit approved are influenced by the frictions of communicating information at distance within the banking organization. Our key explanatory variable is Hierarchical distance, measuring the kilometric distance between the loan officer originating the credit score and the manager(s) to whom the final loan approval decision is delegated.

\footnotetext{
1 These are the same data used in Filomeni et al., 2020. However, unlike our companion paper, we focus here on the loan approval decision and the amount approved.
} 
The estimated empirical models for lending decisions are:

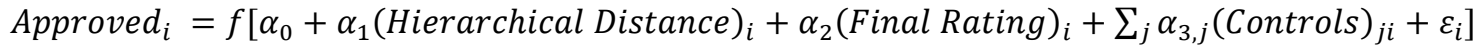

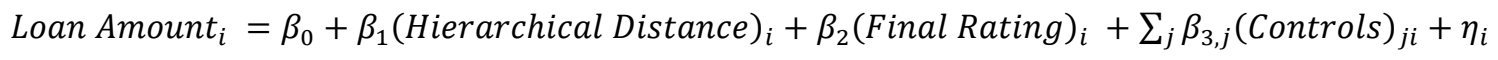

where Approved is an indicator variable assuming values of 1 for approved loans and 0 otherwise, and Loan Amount is the logarithm of the approved credit amount. On average, $87 \%$ of loan applications are approved, while the average size of approved loans is $€ 8,644,876$.

Additional controls include several firm-bank relationship variables described in table 1. First, we control for the credit score of the applicants (Final rating) to take into account the information on applicants' default risk summarized in the credit score by the loan officer and transmitted to higher hierarchical levels. Second, we control for the hierarchical level at which the loan is approved (Approval leve) to wash out possible confounding effects due to the fact that the location of the loan decisionmaker varies with the hierarchical level of approval and this is associated with specific characteristics of loan applicants and applications. Additional controls are the size of the applicant company as measured by the logarithm of total assets (Total assets), the physical distance between the branch where the loan officer works and the headquarters of the applicant company (Branch-to-borrower distance) which banking literature views as reducing information asymmetries and monitoring costs (Petersen and Rajan, 2002; Berger et al., 2005), an indicator variable, Collateral, for the possible collateralization of the credit line, an indicator variable, Scope of relationship, reflecting whether the borrower purchases at least one additional product/service from the bank in order to capture the breadth of the bank-firm relationship. Finally, all regressions include four geographical area and industry dummies to control for unobserved characteristics of local credit market and credit demand that could be correlated with our distance measures, as well as branch dummies to control for unobserved characteristics related both to the demand and supply sides.

As a second step, we analyze whether the impact of hierarchical distance on access to credit depends on whether the automated rating is overridden by the loan officer responsible for the credit 
application by including and transmitting subjective soft information about the loan applicant. We distinguish between positive and negative rating overrides. Specifically, we interact Hierarchical Distance with two indicator variables: Upgrade, which takes value 1 if the final rating assigned to the application $i$ is strictly lower than its integrated rating and 0 otherwise; Downgrade, which takes value 1 if the final rating is strictly higher than the integrated rating:

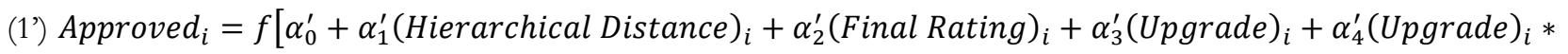
$(\text { Hierarchical Distance })_{i}+\alpha_{5}^{\prime}\left(\right.$ Downgrade $_{i}+\alpha_{6}^{\prime}\left(\right.$ Downgrade $_{i} *$ $\left.(\text { Hierarchical Distance })_{i} \sum_{j} \alpha_{7, j}^{\prime}(\text { Controls })_{j i}+\varepsilon_{i}^{\prime}\right]$

(2') Loan Amount $_{i}=\beta_{0}^{\prime}+\beta_{1}^{\prime}(\text { Hierarchical Distance })_{i}+\beta_{2}^{\prime}\left({\text { Final Rating })_{i}}_{i}+\beta_{3}^{\prime}\left(\right.\right.$ Upgrade $_{i}+\beta_{4}^{\prime}\left(\right.$ Upgrade $_{i} *$ $(\text { Hierarchical Distance })_{i}+\beta_{5}^{\prime}(\text { Downgrade })_{i}+\beta_{6}^{\prime}\left(\right.$ Downgrade $_{i} *(\text { Hierarchical Distance })_{i}+$

$$
\sum_{j} \beta_{7, j}^{\prime}(\text { Controls })_{j i}+\eta_{i}^{\prime}
$$

\section{Results}

In table 2 we report regression results for the decision to approve or reject the loan application (i.e., the extensive margin) and for the amount of credit granted (i.e., the intensive margin). ${ }^{2}$ When we look at the extensive margin, whose results are reported in columns (1) and (3), hierarchical distance has no significant influence on the loan approval decision. With regard to the intensive margin, the results in columns (2) and (4) show that hierarchical distance has a negative and statistically significant impact on the amount of credit granted to the applicant firm. The economic effect of hierarchical distance is equally significant, with a negative elasticity of extended credit to hierarchical distance equal to 0.32 . Since the sub-population of approved loans may be a non-randomly selected sample of the applicant population, and since the unobserved determinants of the propensity to approve a loan and the amount of credit granted may be correlated, we estimate a Heckman correction model (columns (5) and (6) of table 2). As excluded restrictions we use the age (Age) and the years of experience (Experience) of the loan officer responsible for the credit scoring process and an indicator variable capturing whether the

\footnotetext{
${ }^{2}$ In order to focus on loan approval decisions, we exclude from the sample loan applications that reflect an internal credit transfer between the bank and other affiliated banks within the same banking group.
} 
applicant firm belongs to a business group or is stand-alone (Group belonging). On the one side, Age and Experience can be assumed to influence the trust that the senior manager or the committee responsible for loan approval ascribe to credit scoring recommendations that they receive from loan officers, and are likely to have more of an impact on the loan approval decision than on the amount of credit to extend. On the other, Group belonging is included based on the assumption that applicants that are part of a business group may be more valuable to the bank due to their links to other actual, or potential, borrowers. The correlation coefficient between the error terms of the selection and main equations is negative $(-0.027)$, even if the Mills ratio $\lambda$ is statistically not different from zero. Estimated coefficients on variables of interest are broadly consistent with the previous analysis.

Two additional concerns are the positive correlation between Hierarchical distance and Approval level and the fact that the bank's delegation-authority rules require that large loan applications be decided at a high hierarchical level. As a result, it can be difficult to isolate the effect of the geographical distance between bank officers at different hierarchical levels from the effect of a pure organizational friction due to the hierarchical layers through which the loan application travels before a final approval decision is made. To address this concern, we follow the strategy suggested by Liberti and Mian (2009) and limit the analysis to loans approved at the hierarchical levels 3 and 4 . At these two approval levels the officer responsible for loan origination and the officer responsible for loan approval are sometimes located in the same branch and sometimes located in geographically distant branches. Results, reported in model specification (7) of table 2, are consistent with the hypothesis that the geographical location of officers at different hierarchical levels matters for loan approval decisions. In particular, it is interesting to note the magnitude of the adverse effect of Hierarchical distance on the amount of credit granted at approval levels 3 and 4 is greater than the average effect of Hierarchical distance computed by considering loans approved at all hierarchical levels (specifications (1) to (6) in table 2).

[Insert table 2 about here] 
An alternative interpretation of our results could be that the negative impact of Hierarchical distance is due to the lower influence of peripheral branches in the banking organization and their disadvantage in attracting internal resources from the bank's headquarters, more than to communication frictions between distant hierarchical layers. To address this concern, we interact Hierarchical distance with the use of discretionary decisions by loan officers in the form of rating overrides. In order to motivate their score overriding decisions, loan officers are required to prepare detailed written notes to be transmitted with the credit application file to the manager with loan approval authority. Therefore, we test whether the applicant's final rating being equal, the transmission of soft information makes senior bank managers with loan approval authority more cautious towards loan applications coming from peripheral branches relative to loan applications whose credit ratings are generated using only hard and easily "hardenable" information. In a similar spirit with respect to our previous analysis, we estimate models (1') and (2') separately and jointly by using a two-step Heckman model. Estimation results, reported in table 3, are consistent with the hypothesis that the adoption of credit scoring models in corporate lending does not eliminate communication frictions. The transmission of soft information exacerbates the negative impact of Hierarchical distance on credit granted to borrowing firms. However, when we distinguish between downward and upward ratings' overrides, we do find an asymmetric effect. Specifically, the interaction effect of Hierarchical distance with ratings' upgrades turns out to be negative and statistically significant on the loan amount, while that with ratings' downgrades seems to have no effect neither on the likelihood of having the loan approved nor on the amount of credit granted. The negative marginal impact of Hierarchical distance on credit granted to applications subjected to an upward override is more than twice that on loans to applicants whose rating has not been overridden. This stronger negative impact of hierarchical distance for loan applications incorporating soft information confirms that the adoption of CSTs does not erase communication problems within hierarchical banks.

[Insert table 3 about here] 


\section{Conclusions}

In this paper, we contribute to the literature on communication problems in large organizations, by focusing on credit score lending decisions. In particular, we analyze the effects of geographical distance of the senior manager who approves the loan from the loan officer who originates the credit score on the bank loan approval decisions.

Our results indicate that credit scoring does not eliminate the barriers to the unbiased communication of soft information across bank hierarchical layers. Specifically, we find that firms applying to remote branches receive a lower amount of credit than firms with the same score applying to branches closer to the bank office with the final loan approval authority, and that this is especially true for loans whose credit score incorporates soft information subjectively injected by the loan officer. This suggests the persistence of spatially-based organizational frictions within the banking organization despite the adoption of a modern credit scoring-based lending technology. 


\section{References}

Berger, A. N., N. H. Miller, M. A. Petersen, R. G. Rajan, J.C. Stein, 2005. "Does function follow organizational form? Evidence from the lending practices of large and small banks". Journal of Financial Economics 76(2), 237-269.

Bloom, N., Garicano, L., Sadun, R., Van Reenen, J., 2014. The Distinct Effects of Information Technology and Communication Technology on Firm Organization. Management Science 60(12), 2859-2885.

Brown, M., Schaller, M., Westerfeld, S., Heusler, M., 2015. Internal Control and Strategic Communication within Firms - Evidence from Bank Lending. Working Paper Finance No 201504 University of St Gallen.

Filomeni, S., Udell, G.F., Zazzaro, A., 2020. Hardening Soft Information: Does Organizational Distance Matter?. Working Paper.

Gropp, R., Guettler, A., 2018. Hidden gems and borrowers with dirty little secrets: Investment in soft information, borrower self-selection and competition. Journal of Banking \& Finance 87, 26-39.

Liberti, J.M., 2018. Initiative, Incentives, and Soft Information. Management Science 64(8), 3714-3734.

Liberti, J.M., Mian, A.R., 2009. Estimating the Effect of Hierarchies on Information Use. Review of Financial Studies 22(10), 4057-4090.

Liberti, J.M., Petersen, M.A., 2017. Information: Hard and Soft. The Review of Corporate Finance Studies $8(1), 1-41$.

Mocetti, S., Pagnini, M., Sette, E., 2017. Information Technology and Banking Organization. Journal of Financial Services Research 51(3), 313-338.

Petersen, M.A., Rajan, R.G., 2002. Does Distance Still Matter? The Information Revolution in Small Business Lending. Journal of Finance 57(6), 2533-2570. 


\section{Tables}

Table 1. Descriptive Statistics (values expressed in Euro)

\begin{tabular}{|c|c|c|c|c|c|c|}
\hline Variables & Definition & Obs. & Mean & Std. dev. & Min. & Max. \\
\hline \multicolumn{7}{|c|}{ Dependent variables } \\
\hline $\begin{array}{l}\text { Loan } \\
\text { amount }\end{array}$ & continuous variable: logarithm of approved credit [million euros] & 478 & $\begin{array}{c}0.72 \\
{[9.95]}\end{array}$ & $\begin{array}{c}1.95 \\
{[28.79]}\end{array}$ & $\begin{array}{c}-5.52 \\
{[0.004]}\end{array}$ & $\begin{array}{c}6.02 \\
{[410,13]}\end{array}$ \\
\hline Approved & dummy variable equal 1 if the loan application is approved; 0 if it is rejected & 550 & 0.87 & $(\mathrm{NA})$ & 0 & 1 \\
\hline \multicolumn{7}{|c|}{ Independent variables } \\
\hline $\begin{array}{l}\text { Hierarchical } \\
\text { distance }\end{array}$ & $\begin{array}{l}\text { logarithm of } 1+\text { distance in kilometers between the branch where the loan } \\
\text { officer responsible for the credit score operates and the branch of the loan- } \\
\text { approving authority }[\mathrm{km}]\end{array}$ & 550 & $\begin{array}{c}2.67 \\
{[150.6]}\end{array}$ & $\begin{array}{c}2.59 \\
{[294.3]}\end{array}$ & $\begin{array}{c}0 \\
{[0]}\end{array}$ & $\begin{array}{l}7.36 \\
{[1576]}\end{array}$ \\
\hline Final rating & step variable taking values between 1 and 15 , where 1 indicates the highest rating & 516 & 8.02 & 3.68 & 1 & 15 \\
\hline $\begin{array}{l}\text { Approval } \\
\text { level }\end{array}$ & $\begin{array}{l}\text { step variable taking values between } 1 \text { and } 11 \text { according to the hierarchical level } \\
\text { with the power of loan approval }\end{array}$ & 550 & 4.14 & 2.76 & 1 & 11 \\
\hline Total assets & logarithm of total assets [million euros] & 472 & $\begin{array}{l}18.01 \\
{[195]}\end{array}$ & $\begin{array}{l}1.78 \\
{[303]}\end{array}$ & $\begin{array}{c}12.32 \\
{[0.224]}\end{array}$ & $\begin{array}{l}21.59 \\
{[2370]}\end{array}$ \\
\hline $\begin{array}{l}\text { Borrower- } \\
\text { to-branch } \\
\text { distance }\end{array}$ & $\begin{array}{l}\text { logarithm of } 1+\text { distance between the branch the loan officer responsible for the } \\
\text { credit score operates and the headquarters of the applicant company }[\mathrm{km}]\end{array}$ & 550 & $\begin{array}{c}4.39 \\
{[795.7]}\end{array}$ & $\begin{array}{c}2.10 \\
{[2523.3]}\end{array}$ & $\begin{array}{l}0.18 \\
{[0.2]}\end{array}$ & $\begin{array}{c}9.60 \\
{[14753]}\end{array}$ \\
\hline $\begin{array}{l}\text { Scope of } \\
\text { relationship }\end{array}$ & $\begin{array}{l}\text { dummy equal } 1 \text { if the borrower purchases at least one other banking product } \\
\text { from the bank; } 0 \text { otherwise }\end{array}$ & 550 & 0.52 & $(\mathrm{NA})$ & 0 & 1 \\
\hline Collateral & dummy equal to 1 if the credit line is collateralized; 0 otherwise & 550 & 0.39 & $(\mathrm{NA})$ & 0 & 1 \\
\hline Age & age in years of the loan officer responsible for the credit score & 520 & 49 & 6.14 & 29 & 60 \\
\hline Experience & years of experience of the loan officer within the bank & 520 & 21 & 7.95 & 1 & 37 \\
\hline $\begin{array}{l}\text { Group } \\
\text { belonging }\end{array}$ & $\begin{array}{l}\text { dummy equal to } 1 \text { if the borrower is part of an economic group; } 0 \text { if it is a stand- } \\
\text { alone company }\end{array}$ & 550 & 0.89 & $(\mathrm{NA})$ & 0 & 1 \\
\hline $\begin{array}{l}\text { Statistical } \\
\text { rating }\end{array}$ & step variable taking values between 1 and 15 , where 1 indicates the highest rating & 481 & 7.44 & 3.59 & 1 & 15 \\
\hline $\begin{array}{l}\text { Integrated } \\
\text { rating }\end{array}$ & step variable taking values between 1 and 15 , where 1 indicates the highest rating & 483 & 7.68 & 3.40 & 1 & 15 \\
\hline $\begin{array}{l}\text { Uncodified } \\
\text { discretion } \\
\text { (upgrade) }\end{array}$ & dummy variable equal to 1 if final rating $<$ integrated rating, 0 otherwise & $\begin{array}{l}{[62(1)} \\
483(0)]\end{array}$ & 0.13 & $(\mathrm{NA})$ & 0 & 1 \\
\hline $\begin{array}{l}\text { Uncodified } \\
\text { discretion } \\
\text { (downgrade) }\end{array}$ & dummy variable equal 1 if final rating $>$ integrated rating, 0 otherwise & $\begin{array}{l}{[28(1)} \\
483(0)]\end{array}$ & 0.06 & $(\mathrm{NA})$ & 0 & 1 \\
\hline
\end{tabular}

Note: Data are manually collected from our data provider. 
Table 2. Model regressions of loan approval

\begin{tabular}{|c|c|c|c|c|c|c|c|}
\hline \multirow{2}{*}{ Variables } & Probit & OLS & Probit & 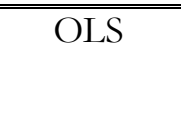 & \multicolumn{2}{|c|}{ "Heckman selection model } & \multirow{2}{*}{$\begin{array}{c}\text { OLS } \\
\\
\text { Loan } \\
\text { Amount } \\
(7) \\
\end{array}$} \\
\hline & $\begin{array}{c}\text { Approved } \\
\text { (1) }\end{array}$ & $\begin{array}{c}\text { Loan } \\
\text { Amount } \\
(2)\end{array}$ & $\begin{array}{c}\text { Approved } \\
\text { (3) }\end{array}$ & $\begin{array}{c}\text { Loan } \\
\text { Amount } \\
(4)\end{array}$ & $\begin{array}{c}\text { Approved } \\
\text { (5) }\end{array}$ & $\begin{array}{c}\text { Loan } \\
\text { Amount } \\
(6)\end{array}$ & \\
\hline $\begin{array}{l}\text { Hierarchical } \\
\text { distance }\end{array}$ & -0.024 & $-0.316^{* * *}$ & 0.039 & $-0.156^{* * *}$ & 0.049 & $-0.137 * * *$ & $-0.429 * *$ \\
\hline & $(0.063)$ & $(0.058)$ & $(0.079)$ & $(0.050)$ & $(0.115)$ & $(0.053)$ & $(0.190)$ \\
\hline Final rating & $\begin{array}{c}-0.072 * * \\
(0.030)\end{array}$ & $\begin{array}{l}-0.023 \\
(0.024)\end{array}$ & $\begin{array}{l}-0.004 \\
(0.041)\end{array}$ & $\begin{array}{l}-0.024 \\
(0.022)\end{array}$ & $\begin{array}{c}0.010 \\
(0.047)\end{array}$ & $\begin{array}{l}-0.013 \\
(0.022)\end{array}$ & $\begin{array}{l}-0.078 \\
(0.053)\end{array}$ \\
\hline Approval level & $\begin{array}{c}0.299 * * * \\
(0.077)\end{array}$ & $\begin{array}{c}0.400 * * * \\
(0.047)\end{array}$ & $\begin{array}{c}0.307 * * * \\
0.039\end{array}$ & $\begin{array}{c}0.251 * * * \\
(0.047)\end{array}$ & $\begin{array}{c}0.374 * * \\
(0.165)\end{array}$ & $\begin{array}{c}0.223 * * * \\
(0.044)\end{array}$ & $\begin{array}{l}0.813^{*} \\
(0.482)\end{array}$ \\
\hline Total Assets & & & $\begin{array}{c}0.151 * * \\
(0.074)\end{array}$ & $\begin{array}{c}0.349 * * * \\
(0.061)\end{array}$ & $\begin{array}{c}0.124 \\
(0.096)\end{array}$ & $\begin{array}{c}0.401 * * * \\
(0.047)\end{array}$ & $\begin{array}{c}0.343^{* * *} \\
(0.126)\end{array}$ \\
\hline $\begin{array}{l}\text { Borrower-to- } \\
\text { branch distance }\end{array}$ & & & $\begin{array}{l}0.161 * * \\
(0.082)\end{array}$ & $\begin{array}{l}-0.066 \\
(0.056)\end{array}$ & $\begin{array}{l}0.174 \\
(0.113)\end{array}$ & $\begin{array}{l}-0.093^{*} \\
(0.054)\end{array}$ & $\begin{array}{l}-0.075 \\
(0.111)\end{array}$ \\
\hline $\begin{array}{l}\text { Scope of } \\
\text { relationship }\end{array}$ & & & $\begin{array}{l}0.741 * * \\
(0.322)\end{array}$ & $\begin{array}{c}1.213 * * * \\
(0.208)\end{array}$ & $\begin{array}{c}0.888 * * * \\
(0.341)\end{array}$ & $\begin{array}{c}1.248 * * * \\
(0.167)\end{array}$ & $\begin{array}{c}1.219 * * * \\
(0.382)\end{array}$ \\
\hline Collateral & & & $\begin{array}{c}0.192 \\
(0.288)\end{array}$ & $\begin{array}{c}0.748 * * * \\
(0.178)\end{array}$ & $\begin{array}{c}0.067 \\
(0.363)\end{array}$ & $\begin{array}{c}0.560 * * * \\
(0.168)\end{array}$ & $\begin{array}{c}0.208 \\
(0.309)\end{array}$ \\
\hline Age & & & & & $\begin{array}{l}0.080 * \\
(0.042)\end{array}$ & & \\
\hline Experience & & & & & $\begin{array}{l}-0.047 \\
(0.036)\end{array}$ & & \\
\hline Group belonging & & & & & $\begin{array}{l}-0.106 \\
(0.473)\end{array}$ & & \\
\hline Mills ratio & & & & & & $\begin{array}{l}-0.036 \\
(0.589)\end{array}$ & \\
\hline Observations & 491 & 449 & 454 & 425 & 429 & 400 & 123 \\
\hline R2 - Pseudo R2 & 0.282 & 0.240 & 0.394 & 0.478 & & & 0.598 \\
\hline Area FE & YES & YES & YES & YES & YES & YES & YES \\
\hline Branch FE & YES & YES & YES & YES & YES & YES & YES \\
\hline $\begin{array}{l}\text { Industry FE } \\
\text { rho }\end{array}$ & YES & YES & YES & YES & YES & $\begin{array}{l}\text { YES } \\
-0.027\end{array}$ & YES \\
\hline
\end{tabular}

Notes. In columns (1), (3) and (5) the dependent variable is Approved, a binary variable equal to 1 if the loan is application is approved and 0 if it is rejected. In columns (2), (4), (6) and (7) the dependent variable is Loan amount, a continuous variable equal to the logarithm of the amount of granted credit. Robust standard errors are reported in parenthesis.

${ }^{* * *} \mathrm{p}<0.01,{ }^{* *} \mathrm{p}<0.05, * \mathrm{p}<0.1$, respectively. 
Table 3. Model regressions of loan approval: distance-discretion interaction

\begin{tabular}{|c|c|c|c|c|}
\hline \multirow[b]{2}{*}{ Variables } & \multicolumn{2}{|c|}{$\begin{array}{ll}\text { Probit } & \text { OLS }\end{array}$} & \multicolumn{2}{|c|}{ Heckman selection model } \\
\hline & $\begin{array}{l}\text { Approved } \\
\text { (1) }\end{array}$ & $\begin{array}{c}\text { Loan Amount } \\
\text { (2) }\end{array}$ & $\begin{array}{l}\text { Approved } \\
\text { (3) }\end{array}$ & $\begin{array}{c}\text { Loan Amount } \\
\text { (4) }\end{array}$ \\
\hline Hierarchical distance & $\begin{array}{c}0.038 \\
(0.080)\end{array}$ & $\begin{array}{c}-0.144 * * * \\
(0.053)\end{array}$ & $\begin{array}{c}0.060 \\
(0.120)\end{array}$ & $\begin{array}{c}-0.115 * * \\
(0.054)\end{array}$ \\
\hline $\begin{array}{l}\text { Uncodified discretion } \\
\text { (downgrades) }\end{array}$ & $\begin{array}{l}0.596 \\
(0.581)\end{array}$ & $\begin{array}{c}0.287 \\
(0.647)\end{array}$ & $\begin{array}{l}0.439 \\
(1.065)\end{array}$ & $\begin{array}{l}-0.202 \\
(0.572)\end{array}$ \\
\hline $\begin{array}{l}\text { Hierarchical distance } \\
\text { Uncodified discretion } \\
\text { (downgrades) }\end{array}$ & (omitted) & 0.013 & 4.259 & 0.071 \\
\hline $\begin{array}{l}\text { Uncodified discretion } \\
\text { (upgrades) }\end{array}$ & $\begin{array}{l}0.224 \\
(0.402)\end{array}$ & $\begin{array}{c}(0.125) \\
0.916 * * \\
(0.379)\end{array}$ & $\begin{array}{c}(0.000) \\
0.130 \\
(0.650)\end{array}$ & $\begin{array}{c}(0.136) \\
0.896 * * * \\
(0.333)\end{array}$ \\
\hline $\begin{array}{l}\text { Hierarchical distanceX } \\
\text { Uncodified discretion } \\
\text { (upgrades) }\end{array}$ & (omitted) & $-0.138^{*}$ & 4.427 & $-0.208 * *$ \\
\hline Final rating & $\begin{array}{l}-0.012 \\
(0.045)\end{array}$ & $\begin{array}{l}(0.087) \\
-0.033 \\
(0.024)\end{array}$ & $\begin{array}{c}(0.000) \\
0.002 \\
(0.049)\end{array}$ & $\begin{array}{l}(0.090) \\
-0.018 \\
(0.023)\end{array}$ \\
\hline Approval level & $\begin{array}{c}0.306 * * * \\
(0.098)\end{array}$ & $\begin{array}{c}0.248 * * * \\
(0.047)\end{array}$ & $\begin{array}{l}0.337^{*} \\
(0.178)\end{array}$ & $\begin{array}{c}0.219 * * * \\
(0.044)\end{array}$ \\
\hline Total Assets & $\begin{array}{l}0.153 * * \\
(0.076)\end{array}$ & $\begin{array}{c}0.355 * * * \\
(0.059)\end{array}$ & $\begin{array}{c}0.132 \\
(0.101)\end{array}$ & $\begin{array}{c}0.406 * * * \\
(0.047)\end{array}$ \\
\hline Borrower-to-branch distance & $\begin{array}{l}0.176 * * \\
(0.090)\end{array}$ & $\begin{array}{l}-0.060 \\
(0.057)\end{array}$ & $\begin{array}{c}0.189 \\
(0.119)\end{array}$ & $\begin{array}{l}-0.082 \\
(0.054)\end{array}$ \\
\hline Scope of relationship & $\begin{array}{l}0.759 * * \\
(0.329)\end{array}$ & $\begin{array}{c}1.195 * * * \\
(0.210)\end{array}$ & $\begin{array}{c}0.899 * * * \\
(0.342)\end{array}$ & $\begin{array}{l}1.236^{* * * *} \\
(0.166)\end{array}$ \\
\hline Collateral & $\begin{array}{c}0.144 \\
(0.291)\end{array}$ & $\begin{array}{c}0.704 * * * \\
(0.174)\end{array}$ & $\begin{array}{c}0.027 \\
(0.382)\end{array}$ & $\begin{array}{c}0.545 * * * \\
(0.168)\end{array}$ \\
\hline Age & & & $\begin{array}{l}0.079^{*} \\
(0.042)\end{array}$ & \\
\hline Experience & & & $\begin{array}{l}-0.050 \\
(0.037)\end{array}$ & \\
\hline Group belonging & & & $\begin{array}{l}-0.102 \\
(0.469)\end{array}$ & \\
\hline Mills ratio & & & & $\begin{array}{l}-0.030 \\
(0.576)\end{array}$ \\
\hline $\begin{array}{l}\text { Observations } \\
\text { R2 - Pseudo R2 }\end{array}$ & $\begin{array}{c}454 \\
0.397\end{array}$ & $\begin{array}{c}425 \\
0.489\end{array}$ & 429 & 400 \\
\hline Area FE & YES & YES & YES & YES \\
\hline Branch FE & YES & YES & YES & YES \\
\hline $\begin{array}{l}\text { Industry FE } \\
\text { rho }\end{array}$ & YES & YES & YES & $\begin{array}{c}\text { YES } \\
-0.023\end{array}$ \\
\hline
\end{tabular}

Notes. In columns (1) and (3) the dependent variable is Approved, a binary variable equal to 1 if the loan is application is approved and 0 if it is rejected. In columns (2) and (4) the dependent variable is Loan amount, a continuous variable equal to the logarithm of the amount of granted credit. Robust standard errors are reported in parenthesis.

${ }^{* * *} \mathrm{p}<0.01,{ }^{* *} \mathrm{p}<0.05,{ }^{*} \mathrm{p}<0.1$, respectively. 